\title{
Threats, Opportunities and Institutional Survival
}

\author{
All matters connected with the Danube were constantly referred to \\ me by the Government, and I attended meetings of the Committee \\ of the Cabinet which was considering the Danube questions in rela- \\ tion to the Conference.
}

JOHN STOKES, [1902]

An Hydraulic Expert

John Stokes (1825-1902) was in his early thirties when, in 1856 , he was appointed Britain's commissioner to the European Commission of the Danube. A graduate of the Royal Military Academy in Woolwich, where he 'learnt all practical military work', Stokes also attended the Military Engineering School in Chatham and went 'through the practical military course of drill, surveying, field works, pontooning, etc.. Ordered to go to South Africa in 1845, the young officer fought in the Zulu Wars and completed engineering works meant to strengthen Britain's newly conquered positions in the colony of Kaffraria. He returned to Britain in 1851, and later served as an Assistant Instructor in Surveying and Field Works at the Royal Marines Academy. Captain Stokes volunteered for the East after his country's involvement in the Crimean War, and in 1855 was entrusted with establishing an Engineer Corps, including both military and civil engineers, that were to support the Ottomans on the Russian front. ${ }^{1}$

1 The quotes are taken from John Stokes, Autobiography (s.l. s.a.), 5-7, online at www.archive .org (visited on 25 March 2017). See also Constantin Ardeleanu, "The Little-Known Autobiography of Sir John Stokes, the First British Representative in the European Commission of the Danube (1856-1871), Analele Universității Dunărea de Jos Galați, Istorie 2 (2003): 87-102 and 3 (2004): 79-90. Presentations of his life and activity in Sidney Lee (ed.), The Dictionary of National Biography: 1901-1911 (Oxford 1912), 424-426 and Who Was Who, vol. 1, 1897-1916 (London 1920), 681. 
While in Istanbul in July 1856, Ambassador Stratford Canning offered him the position of British delegate to the Commission, a proposal stemming from his engineering expertise. Stokes accepted the office, which fitted well with his technical skills, military training and diplomatic ambitions. It was a decision that, Stokes claimed, 'changed my whole life', as he remained at the Danube until the early 1870 s, and his subsequent public career was related to the governance of international waterways. ${ }^{2}$

Stokes' technical background made him quickly understand that the Commission required capable engineers and large financial resources to fulfil its task. He invited Charles Augustus Hartley to become engineer-in-chief (Chapter 4), and Hartley spent most of 1857 completing scientific surveys in the Danube Delta which permitted him to base his technical proposals on solid and relevant empirical data for the river's seasonal variations. Stokes supported the engineering solutions proposed by Hartley and, as detailed in Chapter 5 , played a decisive role in finding the financial means for the completion of the Commission's hydraulic works in the Maritime Danube. He, more than any of the other commissioners, deserves credit for the determination with which he fought to turn the Commission into a permanent institution.

The survival of the Commission, a temporary international organisation with a limited technical mission, is a complex story that goes beyond cooperation and disputes amongst the governments of member states or commissioners themselves. In previous chapters it was shown how the Commission acted as a conflict mediator and a source of security in its jurisdiction. But as an institutional actor in a highly unstable political and economic environment, the organisation was threatened by many factors. From rival infrastructural projects that aimed to absorb the Maritime Danube's share in the profitable grain trade to contestations of its technical reputation, the Commission faced challenges that tested its very existence. By managing such extra-organisational confrontations in its regional setting, it consolidated its public position and proved to be a reliable organ, worthy of being reproduced elsewhere. This chapter aims to follow, by looking at the larger international and regional context, several of the extra-organisational challenges that the Commission faced in the uncertain decade of the 1860 s and early 1870 s, a crucial period for its survival. Stokes will be guiding this excursion, and he is also an excellent example to showcase the influence of the Commission beyond the Maritime Danube.

2 Stokes, Autobiography, 57. 
By 1859, the Commission's works and future was threatened by serious competition from a similarly daring project in the Lower Danubian area - a railway across the province of Dobrudja which was intended to carry Romanian grain via a more secure open seaport. The expected success of this private initiative questioned the very existence of the Commission, so commissioners paid due attention to the first railway to be completed in the Ottoman Empire.

The Crimean War made dozens of western entrepreneurs look for profitable investments in the Black Sea area. One of them was Thomas Wilson, a British capitalist interested in taking advantage of the rich mineral and agricultural products available in the Principalities. In 1855 he published a brochure detailing the economic prospects of the Lower Danube and encouraged the colonisation of 'a most fertile part of Europe'. The Ottoman provinces in the northern Balkans and the Principalities could accommodate millions of lucrative westerners, who were looking for their fortune on continents far away from their European homeland. Such a transfer of population, knowledge and institutions would ensure the prosperity of Europe's southeastern periphery and, with growing commercial links between this area and Western Europe, 'an insurmountable barrier against Russia' would be erected. ${ }^{3}$

Wilson's ideas were vast and ambitious, and they were not mere fantasies. One of his most concrete proposals was the construction of a canal between the Danube and the Black Sea, in Ottoman Dobrudja. According to several contemporary accounts, such a technical enterprise seemed favoured by several natural lakes, a presumptive canal dug by the Romans, and another mouth of the Danube, which would have silted up through the centuries. ${ }^{4}$

After travelling to Dobrudja, Wilson drew up a technical plan and a financial memorandum. He later established a consortium of international investors and sent a certain Forbes Campbell as envoy to Istanbul to get the Ottoman government's consent. An updated technical plan and financial memorandum were backed by allied ambassadors in Istanbul, and eventually the Porte agreed to grant Wilson the right to open the canal and establish free ports at its termini, on the banks of the Danube and of the Black Sea. ${ }^{5}$

3 Thomas Wilson, The Low-Lands of the Danube: Their Reclamation by a Canal from Rassova to Kustandje (London 1855), v-IX.

4 Stoica Lascu, 'Mărturii documentare privind elaborarea unor proiecte ale Canalului Dunăre - Marea Neagră,' Revista de Istorie 37.6 (1984): 534-555.

5 'The Danube Ship Canal, and a Free Port in the Black Sea,' Leeds Mercury, 10, 17 and 24 November 1855; Gheorghe Platon, 'Un episod din istoria canalului Dunărea-Marea Neagră. 
However, by the time Wilson was struggling to get the concession, other British entrepreneurs started to lobby the Porte for a rival project. Charles Liddell, Lewis Gordon and John Trevor Barkley visited the provinces of the Lower Danube and produced a detailed report on the advantages of building a railway across Dobrudja. With a length of only $65 \mathrm{~km}$, it could be easily and cheaply completed. An investment of only $£ 200,000$ for the railway and the harbour works at Cernavodă, plus £100,00o for modernising the harbour of Constanța made this a very profitable project, as it could absorb a great part of the grain that followed the winding and shallow course of the Danube. The plans were well received by capitalists in London, Manchester, Nottingham and Newcastle, who set up a consortium, "The Danube and Black Sea Railway and Kustendje Harbour Co.' (DBSR), to deal with the investment. ${ }^{6}$

Following renewed negotiations, the Porte cancelled the canal concession in September 1857 and decided to go with the railway project. ${ }^{7}$ The entrepreneurs pledged to build the line within three years, and the harbour of Constanța had to be fully operational in five years. The Ottoman government was to provide the DBSR with the free concession of public land and expropriate private properties, at the investors' expense. It was to approve the technical plans and the railway tariff, which could not be altered without its prior consent. At Constanța, the DBSR levied a toll from ships on an equal footing for all flags. Shareholders considered that the contract was highly profitable, and that the railway was capable of revolutionising regional trade and bringing it into the age of predictability. ${ }^{8}$

Construction works started in early 1858 and lasted for two-and-a-half years. Although relatively short and built on flat land, the railway was not easy to complete. Skilled labourers were hard to find and technical materials were

Documente privind proiectul din 1855,' Acta Moldaviae Meridionalis. Anuarul Muzeului de Istorie Vaslui 2 (1980): 335-352 and Stela Mărieș, 'Unveröffentlichte Dokumente in deutschen Archiven über das Projekt des Donau-Meers-Kanalbau (1855-1856), Revue Roumaine d'Histoire 26.3 (1987): 229-243.

6 Charles Liddell and Lewis Gordon, Report on the Proposed Railway between the Danube and the Black Sea, (from Tchernavoda to Kustendjie) and the Free Port of Kustendjie (London 1857).

7 Constantin I. Băicoianu, Sforțările politicei comerciale a Angliei pentru cucerirea Dunării de Jos. Importanța economică a portului Constanța de la Marea Neagră, în trecut și prezent. - O contribuție la politica feroviară și de căi de navigație a României, in: idem, Studii economice, politice și sociale (1898-1940) (Bucharest 1941), 348-349; John H. Jensen and Gerhard Rosegger, 'British Railway Builders along the Lower Danube, 1856-1869,' Slavonic and East European Review 46.106 (1968): 105-128.

8 Gheorghe N. Rugină, Începuturi feroviare pe pământ românesc. 1841-1881 (Bucharest 1994), 180-185. 
expensive. Wetlands posed problems with the stabilisation of the embankment and improving the harbour at Constanța proved more costly than estimated. ${ }^{9}$

The works alarmed the entrepreneurs in Brăila and Galați, who feared that their business would be affected by a structural change in regional trade patterns. Several commissioners were also concerned that the railway would influence Danubian navigation. At a sitting of the Commission, Prussia's commissioner Karl Hermann Bitter started a discussion, and the plenum decided to make a preliminary investigation into the effects of the railway on Danubian trade. Engineer-in-chief Hartley and a certain Fahrenholtz from the Accounting Service were charged with determining if the railway could become a serious competitor for the Danube routeway. ${ }^{10}$

Hartley's report was completed in late October 1859 . The railway had several advantages, as it shortened the distance to Istanbul by about 250 miles, and was considered a rather simple technical accomplishment. Constanța had a good harbour, though the hydraulic works for its modernisation and the construction of workshops and warehouses were far from completed. Without denying the importance of the railway, stating that 'wherever railways were built, they had the effect of increasing agricultural and industrial production at a rate of 75 to $35^{\circ}$ per cent', Hartley concluded that a branch of the Danube had to be improved, as its traffic was guaranteed. He proposed the continuation of the provisional works that the Commission had started at Sulina, although he considered that improving the St George branch was a better solution. The conclusion was self-interested, but there was something true in it. As for Fahrenholtz, his report was a detailed financial analysis of the grain trade during the years $1855^{-1858}$, with the conclusion that the railway was expected to be a great success and thus a serious threat to Danubian trade and to the Commission's task. ${ }^{11}$

The reports were presented to the Commission on 9 November 1859, and commissioners were divided in their opinion about how to proceed with their works. The St George option was again discussed, but as there was a lack of consensus, commissioners decided to request instructions from their governments. There was no denying that the railway could have a major influence on the Commission's revenues, as

9 Henry C. Barkley, Between the Danube and the Black Sea; or, Five Years in Bulgaria (London 1876); Const. Botez, Dem. Urma, Ion Saizu, Epopeea feroviară românească (Bucharest 1977), 99-102; Dumitru P. Ionescu, 'Construirea și răscumpărarea liniei ferate ConstanțaCernavodă,' Anuarul Institutului de Istorie și Arheologie «A.D. Xenopol» 25.2 (1988): 206-209.

10 The National Archives of Romania, Galați Branch, Protocols of the European Commission of the Danube (hereafter PECD), Protocol 101, 21 August 1859.

The reports are attached to ibid., Protocol 109, 9 November 1859 . 
Every quarter of grain that passes by the rail diminishes the revenue of the river - and as the quantity that passes out by the river decreases, so to keep up the revenue must the tax increase, which again will have the effect of sending away more vessels to Kustendjeh.

Stokes considered it important to go on with the St George project, which had more chance of successfully competing against the railway. ${ }^{12}$ But his colleagues were convinced that the Commission would be seriously affected by the railway and demanded the postponement of the Sulina works until it was possible to assess its exact effects on river trade. In March 1860, Stokes was informed that the French government suggested the cancellation of the Sulina works and the introduction of a toll before determining the effects of the railway. Stokes wanted his government to back the St George solution, and he repeatedly emphasised in his report that the French cabinet had no genuine interest in Danubian navigation and were trying to find the easiest solution to get rid of the problem. ${ }^{13}$

In September 186o, France's commissioner, Édouard-Philippe Engelhardt, proposed postponing the improvements at St George and extending the Sulina works. Commissioners from Austria, Prussia, Russia and Sardinia agreed, while the Ottoman delegate requested instructions from his government. Stokes, who was absent at that meeting, later rejected the decision, but it was to no avail. ${ }^{14}$ The St George solution was compromised, and Stokes had to gradually give it up. However, with the success of the Sulina works Hartley and Stokes considered that they had proved the utility of building jetties to improve navigation at the St George mouth. Stokes was alone in this battle, and accused the commissioners from France, Prussia and Russia of covering 'political motivations with technical arguments' to demonstrate the superiority of Sulina and of being unwilling to offer 'the prospect that Europe benefits of the Treaty of Paris. ${ }^{15}$ He received little support from the British Foreign Office, and in May 1861 Stokes agreed to delay works on the southern arm of St George, as it was not appropriate to ask for further financial sacrifices from the Ottoman Empire. ${ }^{16}$

\footnotetext{
12 The National Archives of the United Kingdom (TNA), Foreign Office, FO 78/3215, unnumbered (hereafter unn.) (John Stokes to Earl Russell, Galați, 1 December 1859).

13 Ibid., FO $78 / 3216$ (the same, 29 November 1860).

14 PECD, Protocol 119, 7 September 1860.

15 Ștefan Stanciu, România și Comisia Europeană a Dunării. Diplomație. Suveranitate. Cooperare internațională (Galați 2002), 70-71.

16 PECD, Protocol 128, 13 May 1861.
} 
As for the railway, it did not have the expected economic success. Several reasons accounted for this, including the large transhipment costs at Cernavodă and Constanța, as well as the state of the harbour in Constanța. Over the following decades, the railway managed to attract part of the Danubian grain trade, but not as much as the investors had hoped. ${ }^{17}$

The St George solution resurfaced several times. In 1862, Hartley drew up new plans, building on the experience gained at Sulina, and Stokes tried to find the necessary funding by attracting traders from Brăila, Galați and Ismail to back the project. The proposal was again buried by the opposition of several commissioners. Eventually, as these works 'required the assent of all the Powers, and considerable outlay of money for which H.M. Government is unwilling to incur liability', the British cabinet decided it was more important to permit interested governments to give stability to the temporary works in Sulina. ${ }^{18}$ The railway contributed to sealing the fate of the St George project and ended a long debate between commissioners.

The competition between river and railway, both aiming to attract Danubian grain into global routes, was influenced by the different status of the two ventures. The Commission enjoyed direct support from Europe's Great Powers, and the Ottoman commissioner eased the IO's relations with local authorities and the government in Istanbul; a private company, on the other hand, received less assistance from the Ottoman authorities and was dependent on their goodwill, sometimes paying dearly. As important was the fact that the entire commercial and financial infrastructure in the United Principalities (Romania) converged towards the mouths of the Danube; the Commission took advantage of this, as merchants in the Danubian ports of Brăila and Galați did not hurry to adapt their business practices to the opportunities provided by the railway. ${ }^{19}$

The first round in the competition between the traditional mode of communication (fluvial and maritime navigation) and the 'intruder' (the railway), but also in the race between a political initiative coordinated by a state-backed IO and an economic venture managed by a private consortium (DBSR), both trying to transfer and implant western technology in the periphery, seemed to

17 Ardeleanu, 'Efectele construirii căii ferate Cernavodă-Constanța asupra navigației dunărene (1859-1860),' Analele Universității Ovidius din Constanța - Seria Istorie 3 (2006): 41-54.

18 C.W.S. Hartley, A Biography of Sir Charles Hartley, Civil Engineer (1825-1915): the Father of the Danube, vol. 1 (Lampeter 1989), 145.

19 Jensen and Rosegger, 'British Railway Builders': 105-128; eidem, 'Transferring Technology to a Peripheral Economy: The Case of the Lower Danube Transport Development, 18561928,' Technology and Culture 19 (1978): 680-686. 
have been won by the former. But it was the pressure of the railway that made the Commission speed up its hydraulic works at Sulina. The Commission could claim it won the battle, but its 'triumph' came by adopting the cheapest and most expedient, rather than the best, solution for the long-term development of Danubian navigation.

Another lesson learnt by the commissioners was that, as a transportation infrastructure, the Maritime Danube was part of a very dynamic system. The Commission's techno-political task of regulating river navigation had to stay embedded in this larger commercial framework, and spending money on improving the river needed to have a rational economic base. This made the Commission a close observer of regional political and economic developments and a pro-active organ in fulfilling its institutional task.

The railway did better once the province of Dobrudja was integrated into the Romanian state, which invested heavily in modernising the port of Constanța and in connecting it, via a bridge across the Danube, to the Romanian corngrowing mainland. With these huge infrastructural and functional changes in the early twentieth century, the Maritime Danube (and the Commission) had a strong rival in absorbing the regional grain trade. ${ }^{20}$

As for the canal, proposals for its construction were advanced throughout the late nineteenth and twentieth centuries. They took a more articulate form during the First World War, when Dobrudja was integrated into the Central Powers' war machine, and at the end of the Second World War, when it served not only as a strategic transportation infrastructure of the Soviet bloc, but also as a means of political cleansing in communist Romania. The project was completed in the 1980s, with the support of Romania's dictator Nicolae Ceaușescu, who returned to the same line of reasoning as when the idea was first floated in the nineteenth century - to allow for unobstructed navigation between the Romanian mainland and the Black Sea. ${ }^{21}$

20 Dimitrios M. Kontogeorgis, 'Romanian Danubian and Black Sea Ports during the Nineteenth Century. A Quest for Modernization,' in: Heleni Porfyriou and Marichela Sepe (eds.), Waterfronts Revisited: European Ports in a Historic and Global Perspective (New York 2016), 44-58; idem, "International" and "National" Ports. The Competition between the Ports of Brăila/Galați and Constanța during the Period 1878-1914,' in: Ardeleanu and Andreas Lyberatos (eds.), Port Cities of the Western Black Sea Coast and the Danube. Economic and Social Development in the Long Nineteenth Century (Corfu 2016), 95-128.

21 On the construction of the canal, see David Turnock, "The Danube-Black Sea Canal and Its Impact on Southern Romania,' GeoJournal 12.1 (1986): 65-79 and Wim van Meurs, 'Der Donau-Schwarzmeer-Kanal, eine Großbaustelle des Kommunismus,' Jahrbuch für historische Kommunismusforschung 20 (2012): 113-128. 
Another issue that threatened the Commission's plans came from the attempts of the Romanian state to set up a seaport on the small expanse of seacoast it owned in Southern Bessarabia. In a message to the Romanian Parliament in late 1864, Prince Alexandru Ioan Cuza stated 'that commercial and political needs require the establishment of a [Romanian] Black Sea port,', ${ }^{22}$ through which the country could export its grain resources without the hindrances and taxes of the Maritime Danube. The Romanians wanted Hartley to draw up plans for such a seaport but the engineer initially discouraged the idea for technical and financial reasons. Eventually, he drafted a scheme for a harbour in high seas, at Gibrieni. Stokes was extremely unhappy with the Romanian proposal, wondering why the government wanted a harbour in a faraway corner of the country, on a narrow coast away from the fertile counties that export products and difficultly accessible on land or water. ${ }^{23}$

The project was continued by Cuza's successor, Prince Charles I (Carol) of Romania. In 1867, during one of his visits to the mouths of the Danube, Charles I discussed his plans for the improvement of the Gibrieni Lake, wherefrom 'one could build a canal to the sea, thus getting Romania a sea exit, and a port that would raise the importance of the new Bessarabian districts' that the country acquired in 1856. Financial shortages prevented the execution of the project, although in 1868 the Parliament voted in a law to have the seaport built. ${ }^{24}$

Stokes accused the Romanians of pursuing the seaport as a result of their 'pure jealousy and hostility to Turkey'. Moreover, they wanted to evade European control over their grain exports. Despite such opposition from his close partner Stokes, Hartley continued his collaboration with the Romanians, to whom he gave technical advice. In July 1869 , Hartley presented his plans to Prince Charles I and estimated the costs of constructing the seaport at twenty million francs. ${ }^{25}$

Discussions continued into the mid-1870s, when Hartley's plans for the 'Charles I' port were presented to the Romanian Parliament. The project aimed to link the Black Sea, via a railway, to the rich corn-growing Moldavian districts that lacked good transportation infrastructure. By developing that peripheral region of the country, the port would be able to compete with the

22 Constantin C. Giurescu, Viața și opera lui Cuza Vodă (Bucharest 1966), 396.

23 TNA, FO 78/3221, unn. (Stokes to Russell, Galați, 16 March 1865); Hartley, A Biography, 182-184 and 403-404; Petre Covacef, Cimitirul viu de la Sulina (Constanța 2003), 94-95.

24 Dimitrie A. Sturdza, 'Însemnătatea lucrărilor Comisiunii Europene de la Gurile Dunării, 1856-1912,' Analele Academiei Române. Memoriile secțiunii istorice 35 (1913): 204.

25 Ibid. 
commercial traffic of Odessa without injuring the prosperity of Brăila and Galați. Beyond the seaport's technical challenges, Hartley agreed that the whole project was a 'nationalist' dream of Romania, which could have better improved the Maritime Danube, the country's most vital commercial highway. Discussions around the Gibrieni project continued in the following months, but the outbreak of the war in the Balkans switched the focus away from the seaport. In 1878 Romania lost Southern Bessarabia, but at the same time gained the province of Dobrudja, including the seaport of Constanța, which had been developed by the DBSR. Constanța was to become the new 'Charles I' seaport, getting large investments from the Romanian government that would eventually turn it into a threat to the prosperity of inland Danubian ports.

As for Stokes, his opposition to Gibrieni came from his belief that the Commission had to stay strong by absorbing all local trade and channelling it through the Sulina branch. As in the case of the Constanța railway, every quarter of grain that passed along an alternative export route diminished the revenue of the river and the Commission. In Stokes' calculation, the Danube enjoyed an additional advantage. As an international river with a status regulated by inter-imperial agreements, it was a safer choice for western interests than a domestic port in sovereign waters, where foreign shipping had to follow national legislation.

\section{In Defence of Organisational Reputation}

Antoine Émile Ernest Desjardins was a famous French geographer and historian, and the author of several volumes of historical geography. In 1867 he visited the Lower Danube as an envoy of the French state. He accompanied Prince Charles I in his Danubian tour, advised him on the proposed Gibrieni port, and inspected the Commission's works. Besides reporting to the appropriate French authorities, Desjardins presented his research in front of the French Geographical Society. His view on the Maritime Danube was based on his academic expertise and previous knowledge of the Nile and the Rhône. ${ }^{26} \mathrm{He}$ was fascinated by the identification of ancient settlements, which allowed him to draw conclusions on the long-term variations of the mouths of the respective waterways. In his public speeches, the geographer alluded to the Commission's hydraulic works, and even challenged several of the organisation's technical choices. With such a large living environment as the Danube Delta, the

26 Ernest Desjardins, 'Les embouchures du Danube,' Bulletin de la Société de Géographie 14 (1867): 129-143 
'beautiful maps of the European Commission, made since such a short time, are already far from being accurate today', Desjardins claimed. As for the project of removing the bar by building parallel jetties at Sulina, the geographer did not consider it to be enough. The only viable solution was the maritime canalisation of the Danube. He also thought that Chilia had several advantages over the other two branches of the river. ${ }^{27}$

When Desjardins' papers were published, the Commission felt the need to respond to such defamatory opinions, and letters were sent to the French Geographical Society. Many of Desjardins' assertions were amended in relation to the depth over the Sulina bar, the solution of a maritime canal independent of natural exits, and the differences between the Danube and the Rhône. ${ }^{28}$ Desjardins responded back and referred to several complaints by local merchants as to the quality of the IO's works. He further alluded to the large insurance costs of shipping in the Maritime Danube, as skippers sometimes paid, for a trip from Sulina to Galați, 'a premium almost equal to that paid from Marseille to Sulina'. Desjardins again criticised the choice of branch but praised Hartley's intelligence and diligence. ${ }^{29}$

The Commission replied once more, as Desjardins also did, ${ }^{30}$ this time, however, accusing Hartley of plagiarising the project for the Gibrieni seaport. A new response attempted to settle the dispute and referred to Hartley's original plans that dated back to 1864 , i.e. 'three years before the birth of the priority right claimed by Mr Ernest Desjardins. ${ }^{31}$

A similar defamatory opinion was published in The Globe, a journal from Geneva, which criticised the Commission's dealings, citing the opinion of one of the DBSR's engineers. ${ }^{32}$ Commissioners felt that they needed to defend their work against such unfair incriminations, and Stokes was again the main guardian of the organisation's reputation. Not that everything that the Commission was doing was perfect. But given the difficult conditions in which the Commission had been working, it needed to be defended, as allegations

27 'Note sur la mission de M. Ernest Desjardins aux Bouches du Danube (1),' ibid. 15 (JanvierJune 1868): 90-91, 98 .

28 'Note au sujet d'une communication de M. Ernest Desjardins sur les embouchures du Danube,' ibid.: 268-270.

29 'Réponse de M. Ernest Desjardins à la note de la Commission Internationale des Bouches du Danube,' ibid.: 271-277.

30 'Lettre de la Commission Européenne du Danube à M. Antoine d'Abbadie, de l'Institut, Président de la Commission Centrale,' ibid.: 488-492; 'Réponse à la Lettre de la Commission Européenne du Danube, par M. Ernest Desjardins,' ibid.: 492-493.

31 Hartley, A Biography, 273-274.

32 P. Chaix, 'Le Danube, son cours et ses embouchures,' Le Globe. Revue genevoise de géographie 7 (1868): 137-151. 
risked affecting its image and might make governments decide on its closure. At the same time the Commission was busily engaged in securing a loan for its works (Chapter 5), and public image was crucial in negotiating the term of the agreement. The Commission learnt from such criticism to always respond to accusations and keep the public informed on its own version of things. In time, the Commission's Secretariat acquired a public relations component, important for maintaining a positive and favourable image among stakeholders about the organisation and its works.

\section{5}

\section{Narratives of Institutional Success}

In November 1869 the Commission published a brochure entitled Des effets produits par l'amélioration de l'embouchure de Soulina sur le commerce d'exportation maritime in response to similar contestations from local commercial circles. The memorandum was meant to review the commercial profitability of the Commission's activities, and it serves as a good introduction to the problems that Danubian navigation and trade had faced on the eve of and in the decade that followed the IO's creation in 1856. Though unsigned and assumed collectively by the Commission, its narrative structure and main arguments point to Stokes as one of its main authors.

In fact, from early on in the organisation's history the British delegate insisted on the need to collect detailed statistical information and organise it into coherent series. Commissioners made good use of such data when the Commission prepared the introduction of the tariff in 1860; statistics were also used to prove the progress of navigation - and thus the Commission's efficiency - after the start of its hydraulic and normative works. ${ }^{33}$ Like maps, statistics are instruments of communication, persuasion and power, serving and projecting organisational interests. ${ }^{34}$ Since the late 1850 s, the Commission had started to amass and publish detailed statistics on Danubian shipping, which pushed towards further transnational standardisation in the collection of data and compilation of meaningful quantitative series. They cover a large variety of aspects, from data on the number and tonnage of ships calling at the Maritime Danube to the main goods carried by these vessels and the taxes collected from shipping accidents recorded in its jurisdiction. As interesting

33 PECD, Protocols 89 and 139, 4 November 1858 and 14 November 1861.

34 Denis Wood and John Fels, The Power of Maps (New York and London 1992); Timothy Mitchell, Rule of Experts: Egypt, Techno-Politics, Modernity (Berkeley, Los Angeles and London 2002), 9 . 
are the series on patients in the Commission's hospital or the average temperatures recorded in Sulina and the periods in which the river became frozen.

International commerce on the Lower Danube consisted to a large degree of the foreign trade of the United Principalities (Romania). The exportation of grain was its most rewarding component. As bordering countries did not generally consume foreign grain, Romania's surplus was directed towards seaborne destinations, and Istanbul, Marseille and British ports received 'the most considerable part of the wheat, corn, and barley exported from Galați and Brăila.' ${ }^{35}$ The Danube was the natural transportation channel for this trade. The river and its tributaries served to collect the crops of Wallachia and Lower Moldavia at Brăila and Galați, whence grain was shipped further towards its destinations. An annual average of 2.9 million quarters had been exported for the past four years (1865-1868) through the mouths of the Danube, and about two thirds of this amount came from Romania. Exports were expected to grow considerably, under the 'double impetus given to agricultural production by the new rural law [1864] and the construction of railways and rural roads' in the country. Romania, it was further stated, was the main beneficiary of the Commission's works. The 1856 Paris Treaty had favoured not only the Principalities' political future, but also their economic fate. ${ }^{36}$

The brochure started its analysis of the profitability of the Commission's works by referring to the difficult state of Danubian navigation before 1856 . Based on information from a local commercial house, the depth of the Sulina bar in pre-Crimean War times was reviewed, along with data on its annual variations and the record low depth of 1853 . The Commission contributed to deepening the navigable channel at the Sulina bar to more than 16 feet after the completion of the provisional Sulina piers in 1861, while the navigable depth along the Maritime Danube was increased by about 4 feet. The perils of the shallow waterway were aggravated by the unfavourable position of the Sulina roadstead and the busy lighterage operations carried out in the open sea. With a depth that rarely exceeded 11 feet, most seagoing ships had to lighter at least a part of their cargo. While waiting to reload these goods, ships were exposed to sudden gales, especially in autumn. Seagoing ships were condemned 'to an inevitable shipwreck, and their lighters often shared the same fate. ${ }^{37}$

The Commission had greatly improved this bleak picture. In the late 1860 s Sulina was the best port of refuge on the western coast of the Black Sea, and

35 Des effets produits par l'amélioration de l'embouchure de Soulina sur le commerce d'exportation maritime (Galați 1869), 3.

36 Ibid., 4-5.

37 Ibid., 9 . 
statistics from shipping accidents prove the increased protection it provided to ships (Chapter 7). The organisation had created a lifesaving service in the event of disasters, and there had been no loss of human life recorded in the past decade. However, despite a considerable reduction of the risks to which navigation of the Maritime Danube was exposed, insurance companies failed to make a proportional reduction in the rate of premiums for Danubian shipping, so 'these premiums are always higher than those paid on goods loaded at Kustendje, whose port is much less secure and spacious than that of Sulina'. ${ }^{38}$

As for the savings made thanks to the Commission's works, the brochure calculated them starting with the losses incurred by traders before 1856 . Consular data estimated the average annual expenditure made by captains to lighter their ships at $£ 62,500$, though it was much higher in the exceptional circumstances of the Crimean War. Lighterage fluctuated tremendously depending on demand and the state of the Sulina bar. Skippers also complained about misstatements regarding the capacity of lighters, an issue duly solved by the Commission through its regulations. Unpredictability had been one of the greatest plagues of Danubian navigation that the Commission had to cope with:

It is easy to understand that because of such fluctuations in the rate of lighterage, it was practically impossible for shipowners to evaluate the cost of a voyage to Lower Danubian ports, and it sometimes happened that ships refused to run the risk, even with the prospect of finding cargo for the return to England at the exorbitant rate of 35 s. per quarter. ${ }^{39}$

In actual value, a ship of 400 tons carrying 2,800 quarters of grain paid 3,821 francs for lighterage, lighthouse and pilotage dues at the Danube before 1856 or an average of 1.36 francs per quarter. After the introduction of the Commission's toll in 1860 , a similar vessel would pay 1,320 francs. If it needed to lighter in the river, about 750 francs had to be added, bringing the total cost to 2,070 francs or 0.73 francs per quarter. The organisation could thus claim that its works resulted in a saving of at least 0.60 francs per quarter. This saving was expected to increase to 0.90 francs once the Commission removed the sandbanks and secured a minimum depth of 15 feet along the river. ${ }^{40}$

The number of lighters in the river diminished after 1856, but in the 1860 s there were many large seagoing vessels who waited for their cargo at Sulina,

$\begin{array}{ll}38 & \text { Ibid., } 10 . \\ 39 & \text { Ibid., 11. } \\ 40 & \text { Ibid., 11-13. }\end{array}$


where grain was brought on board fluvial barges, towed in convoy from inland ports. A total of 48 ships loaded their cargo at Sulina in 1861, but in 1868 their number increased to 366 . 'These seagoing ships made, thanks to the Commission's works, an even more considerable economy', as they enjoyed a reduction of 0.50 francs per ton on the taxes paid by seagoing ships that ascended the river.

The Commission's works gave navigation several other advantages. It enabled larger seagoing vessels to call at inland Danubian ports, and thus reduce their overall shipping costs. Ships of 300-400 tons had rarely visited the Danube before the 186os, but in 1869 ships larger than 1,00o tons crossed the bar without the need to lighter. Another advantage was the shorter duration of trips, as ships were 'no longer held at Sulina because of the lack of lighters when they cleared the river', and towage was available at fair prices. Rates previously demanded by tugboats to drive a vessel from the harbour of Sulina or in cases of emergencies were exorbitant. Captains complained that they had paid more than 1,00o francs for a service which in 1869 was provided for a tenth of this sum. The Commission contributed to lowering prices by having a tug specially assigned to assist ship captains with the passage of the Sulina bar for a fixed fee of 60 francs. It was finally the time for predictable voyages, for a new 'politics of calculations', ${ }^{41}$ as

the shipowner and the merchant can now estimate with sufficient accuracy the expenses of a ship sent to the Danube, and estimate the probable benefits of the journey, which was almost impossible for them when lighterage costs varied between 90 and 1,00o francs for a thousand kilas ${ }^{42}$ and when they saw ships ready to go to sea blocked for more than three months at Sulina before being able to cross the bar. ${ }^{43}$

Freight costs had been the clearest proof of the deplorable state of navigation in the Maritime Danube. According to information from local commercial houses, the average cost of the freight paid for first class ships bound from the Danube to British ports was, before the inauguration of the Sulina jetties in 1861 (and leaving aside the extraordinary rates of the Crimean War period), $10 \mathrm{~s}$ $6 \mathrm{~d}$. In the $186 \mathrm{os}$, it decreased to $9 \mathrm{~s}^{44}$

\footnotetext{
41 Mitchell, Rule of Experts, 8-9.

42 A kila in Galați equalled 1 1/2 quarters, and a kila in Brăila 2 1/4 quarters. A quarter was equal to $2.90 \mathrm{hl}$ of grain - Paul Cernovodeanu, Beatrice Marinescu and Irina Gavrilă, 'Comerțul britanic prin Galați și Brăila între 1837-1852,' Revista de Istorie 31.1 (1978), 631, note 6.

43 Des effets, 13-14.

44 Ibid., 15-18.
} 
Other advantages had to do with the damage to the grain cargoes placed on board lighters, which suffered a loss of 7-8 per cent and were sometimes totally compromised for export. The facility by which ships cleared to sea enabled them to dispose of their cargo more quickly, and thus make more frequent and more profitable use of their capital. Before the Commission's hydraulic works, uncertainty reigned in this respect, too. In August 1855, for example, two ships were loaded for England by a commercial house in Galați and left the port five days apart. The first arrived at its destination in November, and the sale of its cargo brought a profit of $£ 800$; the second was held for four months at Sulina and only reached England in June 1856 - the price of grain had fallen, and the grain was sold with a loss of $£_{3,500 .}{ }^{45}$

The authors of the brochure found it difficult to estimate, with any degree of accuracy, the annual benefit that the Commission's technical works and administrative regime brought to Romania's foreign trade. If one made a base estimate of an average exportation of three million quarters and a diminution of costs of two francs per quarter, the profit was larger than the Commission's total expenditure. After the completion of the Commission's works (planned for 1871), its total expenses would reach about sixteen million francs. Beyond

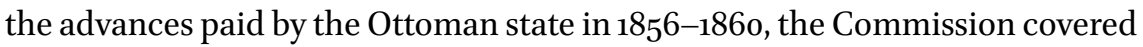
its costs through the proceeds of the taxes it levied at Sulina. It was clear that no burden had been placed on Romania to open an easy outlet for its exports, which could fully enjoy the commercial advantages afforded by the 1856 Paris Treaty. The benefits would further increase after the completion of its works, when the Commission predicted a reduction of its tolls. ${ }^{46}$

The entire brochure breathes an image of corporate success, comparing pre-Crimean War insecurity and the new age of predictability brought by the Commission. Quantitative data was heavily used to showcase economic profitability, which again recall Stokes' opinions on the power of information: after his careful study of the Commission's statistics, 'which were very interesting in showing the growth of trade and its importance to different countries, I was able from time to time to present reports upon them which very much influenced the decisions of my colleagues'. ${ }^{7}$

45 Ibid., 19.

46 Ibid., 20-21.

47 Stokes, Autobiography, 100. 

International Organisation

The Commission rejected the project that diverted the Romanian grain to alternative export routes such as Gibrieni, but several commissioners were interested in strengthening the organisation by opening several of the Danube's larger tributaries up to navigation. By increasing traffic on these rivers, the share of inland Danubian ports in the global grain trade and in the Commission's budget was expected to grow.

The Prut River, stretching over 953 kilometres in Austrian, Russian and Romanian territory and passing through rich corn-growing areas, was important for developing Moldavia's grain export capacities. There had been several attempts to navigate it during the eighteenth and nineteenth centuries by the Ottomans, Russians and Austrians. In the 1840 s the Moldavian government invited a French engineer, Ignace Xavier Morand Hommaire de Hell, to propose a solution for its improvement, and several projects to introduce steamers on the Prut were made. They all failed due to the huge variations in the river's flow and to the many obstacles in its channel. In the post-Crimean War context, a French company tried to open navigation on both the Prut and Siret Rivers, but the initiative was blocked due to a conflict between the Moldavian government and the Ottoman Empire in relation to which authority had the right to grant such a privilege. A shipping company, 'I. Polihroniadi și M.E. Colognomo', was eventually established, and the Moldavian (Romanian) government hired a certain Süren, an engineer who had worked for the Commission, to advise on the technical works to be conducted along the Prut. Süren had to make preliminary studies for river works, as well as for bridges and roads. The engineer stayed in close contact with the Commission, from which he also rented or purchased different materials needed for his works. ${ }^{48}$ By 1864 the Commission allowed Hartley to advise the Romanian government on improving the Prut. ${ }^{49}$

Several commissioners were looking at ways of developing regional trade. Stokes was involved in this and, after visiting the Prut in 1861, estimated that by opening up its navigation 250,000-300,000 quarters of grain could be added to Moldavia's annual export. The Danube's overall trade would thus increase by one tenth. But there was a catch, as by making the Prut navigable, Russia would

48 More on the JCP in Theodor Smeu, Comisia Mixtă a Prutului 1870-1918, PhD dissertation, University of Bucharest (Bucharest 2015); idem, 'Obținerea dreptului Principatelor Române de a încheia convenții: înființarea Comisiei Mixte a Prutului,' Analele Științifice ale Universității Alexandru Ioan Cuza din Iași. Istorie 16 (2015): 265-281. 
return as a riparian state to the Danube. It was, however, highly improbable that a fleet of warships could be maintained on such a small stream, though Russia could claim certain rights according to international law. Stokes visited the Prut again in 1862 and encouraged a Moldovan-Greek-English company to invest in the area. ${ }^{50}$

During the following years negotiations for the establishment of a Joint Commission of the Prut (JCP) intensified. They were led by Henrik d'Offenberg, Russia's Danube commissioner, who discussed the idea with Romanian politicians. Austria was also interested in being part of the project, based on its riparian rights. For the government in Bucharest, the initiative had great political relevance, as it could result in Romania, a vassal country, being recognised as member of an IO on an equal footing with its larger imperial neighbours. An agreement, 'Stipulations on the Navigation of the Prut', was signed in Bucharest on 15 December 1866. Navigation on the Prut was liberalised according to article 16 of the 1856 Paris Treaty. It took several years to have the convention ratified, and the first meeting of the JCP took place on 3 October 1870 at the headquarters of Romania's Foreign Ministry in Bucharest. Russia and Austria-Hungary were represented by their Commission commissioners, Offenberg and Nicholas Zulauf von Pottenburg, and Romania by Panait Donici, the General Inspector of Romanian Railways. In August 1871, an 'Organic Regulation' was adopted, followed by several other internal regulations, all drafted by Edmond Mohler, the Commission's secretary general, paid to support the establishment of the younger organisation. ${ }^{51}$

The permanent seat of the JCP was settled in Galați, and the Commission was an important supporter of its sibling institution. The JCP carried out hydraulic works for the improvement of the Prut riverbed, but they did not go very well due to the organisation's financial shortages. Despite a slight increase in navigation and trade on the Prut, the JCP was far from being as profitable as the Commission. ${ }^{2}$ This precariousness shaped the structure of its bureaucracy, with the JCP's engineer, a certain Guido Edler von Toncourt, also acting as its Navigation Inspector.

The Commission provided the JCP with important favours. It allowed its bureaucrats and technocrats to work extra time for the smaller organisation. Expertise and technical equipment were provided at a fair price, so the

$50 \quad$ PECD, Protocol 134, 23 July 1861; NAR, Galați Branch, The European Commission of the Danube, the English Delegate Fund, File 7, f. 46-49.

$51 \quad$ Smeu, Comisia Mixtă a Prutului, 91-92.

52 Alexandru Duță and Stanciu, 'Amenajarea pentru navigație a râului Prut la sfârșitul secolului al XIX-lea și începutul secolului al XX-lea,' Danubius 11-12 (1986): 190. 
Commission contributed tremendously, together with the three state actors involved in the JCP, to the activity of its younger sibling. The JCP was eventually abolished at the end of the First World War when, following territorial changes in southeastern Europe, the entire navigable section of the Prut River became part of Greater Romania.

\section{$7 \quad$ The London Conference (1871) and the Prolongation of the Commission}

Running the Commission's daily business, Stokes added to his technical background a solid understanding of the juridical, administrative and nautical aspects of inland navigation. In dealing with the Ottoman authorities in the Danube Delta and Istanbul, he also perfected his expertise in Oriental politics and diplomacy. He was a persevering author of detailed reports with which he bombarded his superiors, who initially paid little attention to them. But in Istanbul, Vienna and Galați, Stokes was regarded as one of the most qualified experts in European inland navigation.

When Russia denounced the neutralisation of the Black Sea in the context of the French-German war of 1870, Stokes

wrote very strongly to Lord Granville [the Foreign Secretary] on the subject, setting forth the view that English interests were of such paramount importance in the Danube that Great Britain ought to maintain its share in the control of the river, which, under present arrangements, was only extended to the Spring of 1871 . I urged that this was an excellent opportunity, while conceding points to Russia, for insisting on our permanent hold upon the Danube. ${ }^{53}$

In December 1870 Stokes proceeded to Vienna, having been invited there to discuss the Danube Question by representatives of the Austrian cabinet. ${ }^{54}$ It was 'a great compliment to me' and an overt recognition of his expertise. He met top statesmen in the Hungarian and Austrian capitals, and they agreed

53 Stokes, Autobiography, 102.

54 TNA, FO 78/3226, unn. (Stokes to Earl Granville, Galați, 6 December 1870 and Vienna, 11 December 1870). 
that 'if the Russian power was to be re-instated in the Black Sea, the European control over the mouths of the Danube ought certainly to be perpetuated. ${ }^{55}$

Stokes left for London and, after a cold welcome, his relations with the Foreign Office became 'of the most frequent and satisfactory character'. His services came to be highly appreciated by his superiors and, as quoted in the motto above, played a vital part in pushing all parties towards an agreement. Eventually, Stokes 'drafted the Articles of the Treaty [13 March 1871] which embodied the rules for the maintenance of the Danube control'. Bargaining for mutual concessions between imperial powers secured a good agreement, which extended the Commission until 24 May 1883, allowing it enough time to repay the loan taken out in 1868 . Other provisions were: the functioning of the Riverain Commission could be decided through a preliminary understanding among riparian states; Austria and the Ottoman Empire could conduct necessary works at the Iron Gates; the operations, establishments and vessels of the Commission were declared neutral and its administrative and technical staff enjoyed immunity; and the Ottoman Empire, as a territorial power, was exempted from the neutrality regime. ${ }^{56}$

The London Conference was yet another event that can be analysed within Europe's new ideological framework - the gradual emergence of internationalism after 1815, with an increasing number of conferences to settle disputes and which contributed to the making of a European system of law. ${ }^{57}$ In larger inter-imperial political struggles, the Maritime Danube and the Commission were used as bargaining chips for securing Europe's balance of power. Smaller vassal states in the area, Serbia and Romania, took advantage of the diplomatic gathering and tried to make their voices and causes heard by their imperial guarantors, although without much success. ${ }^{58}$

\section{Gordon's Disinterest in the Commission}

By the early 1870 s the Commission was a functional organisation that had created a security regime along the Maritime Danube. According to the ${ }_{1865}$ Public

55 Stokes, Autobiography, 103. His official correspondence from this period in TNA, FO 78, file 3227 .

56 Treaties and Other Documents relating to the Navigation of the Danube. 1856-1875 (London 1878), 37-38.

57 Mark Mazower, Governing the World: The History of an Idea, 1815 to the Present (London 2012).

58 Ian D. Armour, 'The Sensitivities of Small, Backward Nations: Austria-Hungary, Serbia, and the Regulation of the Danube 1870-71,' Canadian Journal of History 47.3 (2012): 515-544. 
Act it enjoyed legislative, executive, administrative and juridical powers that made it capable of regulating and controlling navigation over its jurisdiction. Stokes was one of the main craftsmen of this transnational organ which 'held the somewhat unusual position of legislating for the navigation, administering the laws by its agents and, finally, judging the cases on appeal'.59 After fifteen years at Galați, Stokes could boast that he was controlling the Commission, as 'the long experience gained since 1856 gave me a preponderating influence at our council'.60

Thrilled by his long expected and fully deserved diplomatic success, Stokes decided it was time to leave his post, but not before a suitable replacement was found and appointed. When 'Col. Gordon R.E., of Chinese fame' accepted the position, Stokes had good reason to see British interests in safe hands. ${ }^{61}$

By the summer of 1871 , Stokes and Hartley had affirmed the official appointment of a new British commissioner, Charles George Gordon (1833-1885), another officer with technical training that had proved useful during the Crimean War, when Gordon surveyed enemy positions in the Crimea. Gordon's technical abilities had secured him an appointment as a consultant in the international commissions that in $1856-1858$ settled the new Russian-Ottoman border in Bessarabia and Asia Minor. After a short stay in Britain, he volunteered for China, where he contributed decisively to crushing the Taiping Rebellion. He returned home as a hero but enjoyed little popularity among the local elites due to his peculiar social and religious views. ${ }^{62}$

Gordon arrived at Galați in late 1871 to find out he had accepted an office that required different qualities than those which had made him famous. In December, Stokes reported that Gordon was busily studying the Commission's archives and getting ready for his post. ${ }^{63}$ But, as Stokes started to fear, such an adventurer found 'too little to exert his energies upon' in the diplomatic routine of an IO. Moreover, Gordon was not 'in favour of English predominance' in the Commission. ${ }^{64}$ As soon as Stokes left, Gordon gave vent to his true feelings, and in private letters and public discussions started to deride Stokes, whose

\footnotetext{
59 Stokes, Autobiography, 84.

60 Ibid., 101,

61 Ibid., 105.

62 Details on Gordon's life in Baron Godfrey Elton, General Gordon (London 1954). His connections to the Lower Danube in E.D. Tappe, 'General Gordon in Rumania,' Slavonic and East European Review 35 (1956-1957): 566-572.

63 Hartley, A Biography, 292.

64 Stokes, Autobiography, 106; Hartley, A Biography, 292.
} 
mind 'was quite warped as to the import of the place which makes me wonder the Government care to keep an officer here'.65

Gordon's temperament made him less interested in preserving a strong British voice in the Commission's affairs. Hartley was the first victim of Gordon's egalitarian views when the new commissioner got upset with the terms of the engineer's contract. Hartley accepted a renegotiation of his appointment, and Gordon gradually came to appreciate Hartley's technical abilities and balanced temperament. ${ }^{66}$

Gordon despised the Commission and the boring work he had to do in an organisation that treasured order and bureaucratic monotony. He eventually moved from Stokes' former house and spent most of his time in the seclusion of the Danube Delta. He even wanted to move the Commission's headquarters to Sulina, a proposal duly rejected by the Foreign Office (Chapter 3). His thoughts were elsewhere, and he showed no interest in Danubian shipping or in promoting the cause of his organisation. ${ }^{67}$ Gordon seized the earliest opportunity to leave, and when he went to Africa in 1873 , few people at the Danube regretted his departure. Stokes himself was relieved to know that his institutional heritage would hopefully go to safer hands.

\section{Stokes' Epistemic Communities}

Stokes' example is illustrative of the making of experts during the second half of the nineteenth century. Several factors made their knowledge extremely sought after by European decision-makers. It was a period of intense colonial expansion, fuelled to a large extent by the development of railways and steam shipping. Central governments and private investors went hand in hand in connecting the West and the rest of the world in formal and informal empires, and in many regions inter-imperial cooperation for specialised 'domains or issue areas' was vital in diminishing the risk of conflict. Huge infrastructure projects aimed to remodel geographical landscapes and shape them according to transnational economic needs, and they required cooperation between imperial authorities and local actors. Negotiating interests in all these vitally important peripheral areas involved not only diplomatic skills but also expertise.

\footnotetext{
65 Hartley, A Biography, 293.

66 Ibid., 294-300; the new conditions in PECD, Protocols 274 and 283, 4 May 1872 and 16 September 1873 .

67 Hartley, A Biography, 302-303.
} 
Stokes is a good example of what such expertise meant in the late nineteenth century. He was appointed to the Commission for his engineering background but soon enough, he and the other commissioners shifted their focus from technical aspects to administration, trying to establish a stable and secure political environment in an anarchical peripheral Ottoman province. The Commission started to draft legislation for an international river and in doing so, commissioners and bureaucrats needed to align it with Ottoman law, the privileges of foreign citizens in the Ottoman Empire and their own national legislation. This imposed a great degree of cooperation at a pan-European level and information exchange with governments, private companies and academics around Europe.

Stokes knew how professional knowledge was produced and he enjoyed being a 'technical adviser' on matters related to hydraulic projects and colonial rule in the Ottoman Empire. His government, however, 'discovered' him and his expertise only at a critical juncture, when the British authorities needed to make a decision about the remilitarisation of the Black Sea in 1870-1871. In this, Stokes followed in the footsteps of several of his colleagues, whose expertise was employed by their governments in the regulation of inland navigation, such as Karl Hermann Bitter, the Prussian commissioner who was transferred to the Rhine Commission in 186o, or Austria's Franz Karl von Becke, employed to administer the port of Trieste. Stokes managed to convince his government of the importance of the Maritime Danube for British and larger European interests. Later in his life, this knowledge made him part of numerous other expert communities connected to every aspect of international rivers, canals, harbours, navigation tariffs and tonnage.

In 1873 , Stokes was appointed as one of the two British commissioners in the International Tonnage Commission that assembled in Istanbul for settling uniform measurement rules for the tonnage of ships passing through the Suez Canal (Chapter 5). A compromise was reached, which marked the beginning of a fruitful cooperation between Stokes and Ferdinand de Lesseps. While in the Ottoman Empire, the British government ordered him to report on the condition and administration of the Suez Canal Company (SCC), and Stokes advised on the desirability of transferring its administration and maintenance from the hands of a private company to the direction of a public authority. ${ }^{68}$

In January 1875, Stokes was appointed Commanding Engineer at Chatham, allowing him to unite his functions at the Foreign Office with those of a military nature. However, the government was soon informed about the

68 Stokes, Autobiography, 119-123; Obieta, The International Status, 56. 
financial difficulties of the Egyptian Khedive, who was negotiating with various French capitalists over the sale of his SCC shares. Lord Tenterden, the permanent under-secretary of the British Foreign Office, consulted him on the advisability of purchasing these shares, and Stokes attended a meeting of the British cabinet. When called upon to give an opinion as to whether a purchase should be made, he 'strongly advocated this course' and then 'put in a strong Memorandum giving full particulars of the Canal Company and of the Khedive's financial needs'.69

Stokes was instrumental in Britain's acquisition of the SCC shares. In his memoirs, he proudly referred to his activity as a 'technical adviser' to the British government in all matters connected with the Suez Canal. ${ }^{70}$ Stokes later visited Egypt and eventually convinced F. de Lesseps to sign an agreement, under which the latter withdrew his protest against European powers, on condition that the British cabinet could get the Great Powers to accept that compromise. Lesseps also agreed to have three directors in the SCC appointed by the London cabinet, and Stokes was one of them. The second was Rivers Wilson, appointed by the Treasury to represent Britain's financial interests, and the third was Edward James Standen, who had been Stokes' private secretary for his entire term as British representative in the Danube Commission and whom we met in Chapter 5 :

The technical knowledge which he [Standen] had acquired on all matters connected with the Danube works during his long service with me and his acquaintance with the French language pointed him out as a valuable man to name as Director to reside in Paris and look constantly and closely into all matters of the Suez Canal Company. ${ }^{71}$

Stokes remained a director of the SCC until his death in 1902, and his contribution to solving things satisfactorily for British interests secured him a knighthood (ксв). During the last decades of the nineteenth century, he was involved in many other projects where his expertise seemed useful: he took part in the Panama Congress promoted by F. de Lesseps; he led an international commission (which assembled in Paris in 1880) appointed to examine the works necessary for the improvement of the port of Alexandria and decide on a fair tariff on shipping; he was a member of the British Royal Commission on Tonnage Measurement, in continuation of his expertise from the Danube

\footnotetext{
69 Stokes, Autobiography, 127-128.

$70 \quad$ Ibid., 128.

$71 \quad$ Ibid., 135 .
} 
and the Suez; he served as an advisor for the Royal Commission of Colonial Defence on matters related to the Suez Canal; he was a member of a committee appointed by the Secretary of State for War 'to enquire into certain points in connection with a proposed Sub-Marine Tunnel to connect, for railway purposes, the English and French coasts'; and he served as board member for a company aiming to cut a canal deepening the passage through the straits between Ceylon and India, in order to shorten the voyage to Calcutta. In 1887 Stokes was made a vice-president of the SCC and was later allowed to remain in office after his 7oth birthday, as the British cabinet recognised that there was no successor who could have a similar influence in the company. ${ }^{72}$ Indeed, his example clearly shows that, as pointed out by Canay Ozden, hydraulic science moved between colonial centres and its bearers carried with them not only expert knowledge, but also a colonial mindset that governed their drive for 'civilising' both society and nature. ${ }^{73}$

The survival of the Commission in the uncertain decade of the 186os was a complex story in which political decisions of member states (such as at the 1871 London Conference) played an important role. But the organisation itself, including its diplomatic leadership (commissioners) and its executive layer (bureaucrats), deserves much credit for its institutional resilience. This chapter alluded to two ways in which the Commission acted to showcase its efficiency and defend its image: investments in the commercial potential of the Maritime Danube and building up a reputation of professionalism.

The first resulted from the organisation's role within the regional economic system. The Commission worked to streamline navigation along a transportation highway which competed with other infrastructures for a share of the profitable grain trade. The Cernavodă-Constanța railway and the Romanian plans to open a new seaport in Southern Bessarabia rivalled the prospects of the Maritime Danube, and the Commission closely followed these projects which eventually influenced the commissioners' hydraulic decisions. At the same time, the Commission got involved in initiatives designed to increase the

72 Ibid., 188.

73 Canay Ozden, 'The Pontifex Minimus: William Willcocks and Engineering British Colonialism,' Annals of Science 71.2 (2014): 183-205; see also Jessica B. Teisch, Engineering Nature: Water, Development and the Global Spread of American Environmental Expertise (Chapel Hill 2011). 
commercial output of the Maritime Danube by opening up the trade of other rivers, such as the Prut. This resulted in the establishment of a sibling IO, the JCP, supported by all commissioners, as it gathered together the two imperial powers, Russia and Austria-Hungary, who contested the articles of the 1856 Paris Treaty which stood at the foundation of the Commission.

The second has to do with public image and the importance of saving reputation at a time when the Commission was trying to secure a larger international loan for its hydraulic works. The organisation decided to respond to public articles which incriminated its technical choices and works in the Danube Delta and, at the same time, started to publish brochures in which it exhibited its efficiency, based on detailed quantitative data. The quality of the Commission's hydraulic programme and its normative works, commissioners claimed, clearly resulted from statistics that aimed to show that Danubian skippers and merchants, the taxpayers of the Commission's budget, had made large profits out of the IO's activity.

The survival of the Commission was equally the result of personal commitment from some of its founding fathers, who sincerely believed in this supranational project. Stokes and several colleagues in the Commission (both in the diplomatic service and the bureaucratic apparatus) devoted much of their knowledge and energy to the organisation. As happens in such cases of organisational commitment, this institutional craftsmanship nourished their emotional needs for professional achievement, and completely transformed their future careers. Stokes, the hero of this chapter, came to develop paternal feelings for his institutional offspring and remained attached to the Commission throughout his life.

Stokes is equally representative of the Commission's gradual evolution into a 'community of experts'74 in transboundary rivers, a specialisation that combined knowledge in seamanship, international law and engineering. ${ }^{75}$ Stokes used well the expertise he gained at the Danube and carried it with him towards other colonial areas where he was appointed to serve British and larger transnational interests: the Suez, Alexandria and India.

74 Martin Kohlrausch and Helmuth Trischler, Building Europe on Expertise. Innovators, Organizers, Networkers (Basingstoke 2014); Wolfram Kaiser and Johan W. Schot, Writing the Rules for Europe: Experts, Cartels and International Organizations (Basingstoke 2014). More on this in Luminița Gătejel, 'Imperial Cooperation at the Margins of Europe: the European Commission of the Danube, 1856-65, European Review of History/Revue européenne d'histoire 24.5 (2017): 781-80o. 